\title{
Political Stability and Financial Development: Evidence from Turkey
}

Zehra DOĞAN ÇALIŞKAN ${ }^{1}$

Article Info

Article History:

Date Submitted: 30.07.2019

Date Accepted: 01.08.2019

Jel Classification

C01, C13, C82, E61, F65.

Keywords:

Political Stability,

Political Instability,

Financial Development, Turkey.

\begin{abstract}
The interaction between political decisions and economic indicators constitutes the main subject of political economy and it surfaces the performance that policymakers display in the point of the solution of economic problems. In other words, the most significant results of political decisions have been seen in the field of economy. In this regard, the stability of political decisions and the existence of political stability which is defined as political order affect economic order, development and stability as well. The economic stability that affects the welfare level of one country have several determinants like the macroeconomic indicators such as general level of prices, rate of employment, level of production and balance of payments, and the continuity of political order, the size of military power, corruption, accountability in politics, political transparency and fair distribution of income. In this study, on the other hand, how political stability affects financial development in the field of economy has been researched. For that purpose, Granger causality test has been applied for Turkey by using the data of financial development and political stability belonging to the years of 19702017. In the result of analysis, a long-termed relationship between financial development and political stability was discovered and a causality from financial development to political stability was discovered as well.
\end{abstract}

\section{Introduction and Literature}

Although political stability does not have a consensus in the study for the meaning in the studies usually, by defining political instability, an opinion has been tried to gain. In other words, in order to define political stability, what political instability should be propounded. While Lipset (1960) defines the political instability as a state of non-existence of political stability, democracy and opposition, Marrison and Stevenson (1972) expressed that political instability cannot have a global definition but it can be defined as the disruption of national political system. Ake (1975) mentioned political behavior and political structure while he defined the political instability. According to this, political instability has been used in the

\footnotetext{
${ }^{1}$ Dr. Öğr. Üyesi, Bolu Abant İzzet Baysal Üniversitesi, Gerede Uygulamalı Bilimler Yüksekokulu.
} 
policies to express periods that certain rules and behaviors cannot be formed, and order cannot be provided with the law and acts. Mbaku (1988) defined political instability as the nonexistence of global behaviors and the similar policies that have been applied in various countries. Fosu (1992) defined political instability as the sum of government, administration, regime and nation that do not have the stability. According to Alesina and Perotti (1993), political instability is a two-dimensional problem as social unrest and political violence. Alesina (1996) defined political stability as not having the ability to go through the changes in both institutional and non-institutional fields. According to Berthelemy et al. (2002), political instability can be defined with some risk indicators. These are; absence of opposition, disregarding civil media and the view of society, exclusion of some fractions in the society both socially, economically and politically, youth unemployment, impoverishment and the increase of inequalities, the violations of human rights, the increase of political distrust and migration waves. By indicating that both political stability and political instability should be redefined in American economy, Margolis (2010) stated that stability and instability have different elements in terms of a new point of view and one concept cannot be defined as the reverse of it.

The relationship of economic growth with political stability has been mentioned frequently in the literature because the first impact of stability is on economic growth. In these studies (Feng: 1997, Gür and Akbulut: 2012, Karahan and Karagöl: 2014, Uddin et al. 2017, Diken et al. 2018), although the definitions of political stability change, broadly, it is possible to mention the long-termed and positive impact of stability indicators on economic growth. In the studies that follow a similar point of view (Alesina et al. 1996, Asteriou and Price: 2001, Koirala et al. 2005, Jong A Pin: 2008, Aisen and Veiga: 2010, Şanlısoy and Kök: 2010, Kouba and Grochova: 2011, Arslan: 2011, Gurgul and Lach: 2013, Kalay and Çetin: 2016, Tabassam et al. 2016, Doğan Çalışkan: 2018), a negative-oriented relationship (the impact when political instability increased, growth will be decreased) between indicators of political instability and growth mentioned.

In their study, Roe and Siegel (2011) advocated that political instability will slow economic growth down by mentioning the hindrances in front of financial development. According to this, financial development is considered as a necessary and beneficial way for countries to start and sustain a proper process of economic growth. In this sense, political risks and uncertainties that will hinder financial development should be avoided. 
In their studies, Compos et al. (2012) analyzed the impact of financial development and political instability as a dual dilemma on economic growth. According to the first result of analysis that they made in the period of 1996-2000 for Argentinian economy, financial development increased volatility in growth in relevant country. According to the second discover of analysis, there is a solid relationship between political decisions that have been taken about financial liberalization and growth.

The relationship of political stability and financial development has been analyzed in the horizon of economic growth. According to this, political stability introduces economic growth with the way of financial development as well. In other words, financial development and depth are the factors that call forth the economic bond between political stability and growth. However, no study was not found about the direction and intensity of relationship between financial development and political stability in the literature. In this regard, the relationship between political stability and financial development for Turkey will be examined in the study.

\section{Dataset and Method}

Theoretical and empirical literature revealed the close relationship between political stability and financial development. The contribution of this study to the literature is to test the long-termed relationship between political stability and financial development for Turkey in the relevant period. On that purpose, Polity IV risk indicators and stock market index values have been subjected to analysis for Turkey in the years of 1970-2017. In order to test the relationship between these two variables, unit root, Johansen cointegration and Granger causality analyses have been used within the fame of Vector Autoregressive Model (VAR) model analysis.

\section{Result of Analysis}

The series have been subjected to stability analysis in the first stage of model. In the study, Augmented Dickey-Fuller (ADF) and Phillips-Peron (PP) unit root tests that have been frequently used in the literature have been applied to the series. Whether the variables are stable has been researched and only when the first differences has been taken, it was detected that two variables are not stable in the values of level. The ADF and PP unit root test results can be seen in Table 1. 
Table 1. Unit Root Tests Results

\begin{tabular}{|c|c|c|c|c|c|}
\hline & \multicolumn{2}{|c|}{ ADF } & \multicolumn{2}{|c|}{ PP } \\
\hline & & Intercept & Trend Intercept & Intercept & Trend Intercept \\
\hline \multirow[t]{2}{*}{ Ifinance } & $I(0)$ & 0,713184 & $-0,481117$ & 0,587382 & $-0,578912$ \\
\hline & $\mathrm{I}(1)$ & $-5,048497^{\star}$ & $-5,267757^{\star}$ & $0,587382^{*}$ & $-0,578912^{\star}$ \\
\hline \multirow[t]{2}{*}{ Ipolity } & $I(0)$ & 0,461611 & $-1,959686$ & 0,493773 & $-2,110789$ \\
\hline & 11) & $-6,267166^{*}$ & $-6,303287^{*}$ & $-6,266961^{*}$ & $-6,298551^{*}$ \\
\hline
\end{tabular}

*: 0,01 significance level

Whether the variables are affected from the similar shocks after the unit root tests, in other words, the question whether they have acted in unison has been researched with the aid of Johansen cointegration test. Obtained discoveries demonstrate that two cointegrated equilibrium was found in 0,05 significance level. Cointegration test results can be seen in Table 2.

Table 2. Johansen Cointegration Test Results

\begin{tabular}{|c|c|c|c|c|}
\hline Hypothesized & & Trace & 0.05 & \\
\hline No. of $\mathrm{CE}(\mathrm{s})$ & Eigenvalue & Statistic & Critical Value & Prob. ${ }^{* *}$ \\
\hline None * & 0.318285 & 27.95045 & 15.49471 & 0.0004 \\
\hline At most 1 * & 0.258125 & 12.24154 & 3.841466 & 0.0005 \\
\hline \multicolumn{5}{|c|}{ Unrestricted Cointegration Rank Test (Maximum Eigenvalue) } \\
\hline Hypothesized & & Max-Eigen & 0.05 & \\
\hline No. of $\mathrm{CE}(\mathrm{s})$ & Eigenvalue & Statistic & Critical Value & Prob. ${ }^{* *}$ \\
\hline None * & 0.318285 & 15.70891 & 14.26460 & 0.0294 \\
\hline At most $1^{*}$ & 0.258125 & 12.24154 & 3.841466 & 0.0005 \\
\hline
\end{tabular}

The results of Granger causality test that has been made in order to determine the direction among the variables set forth a unilateral causality from financial development to political stability. Granger causality test results can be seen in Table 3 . 
Table 3. Granger Causality Test Results

\begin{tabular}{|c|c|c|c|}
\hline \multicolumn{4}{|l|}{ Dependent variable: DFinance } \\
\hline Excluded & Chi-sq & df & Prob. \\
\hline DGSYH & 1.104324 & 2 & 0.5757 \\
\hline All & 1.104324 & 2 & 0.5757 \\
\hline Dependent variable: DPolity & Chi-sq & df & Prob. \\
\hline Excluded & 7.204320 & 2 & 0.0273 \\
\hline DLFG & 7.204320 & 2 & 0.0273 \\
\hline All &
\end{tabular}

\section{Assessment and Conclusion}

In the study, political risk and instability, in other words, the relationship between political stability and financial development specific to Turkey has been analyzed. According to the results of analysis, a long-termed and interactive relationship between political stability and financial stability exists. In this regard, executions and decisions in the fields of finance and politics affect each other. The dominant direction of effect is from financial development to political stability. In other words, if the financial development changed for better (in a direction that welfare can be generated, and growth and investments can be increased), it would affect political stability positively. From a different viewpoint, stopover or decline in financial development generate political instability. Political stability and financial development are interacting variables to each other for Turkey. Policymakers should consider properly the dynamics of those field when they are making a decision. 


\section{References}

Aisen, A. ve Veiga, F.J. (2010), How Does Politıcal Instability Affect Economic Growth? Central Bank of Chile Working Papers No: 568, 1 - 40, Available: https://www.imf.org/external/pubs/ft/wp/2011/wp1112.pdf.

Ake, C. (1975), A Definition of Political Stability, Comparative Politics, Vol. 7, No. 2, pp. 271-283, Available:http://www.jstor.org/stable/421552.

Alesina A. ve Perotti R. (1993), Income Distrubition, Politicial Instability, and Investment, Europan Economic Review, 40 (6), 1203-1228. doi:10.1016/0012921(95)00030-5.

Alesina, A. ve Özler S. ve Roubini, N. ve Swagel, P. (1996), Political Instability and Economic Growth, NBER Working Paper Series, No. 4173 Available: http://www.nber.org/papers/w4173.

Arslan, Ü. (2011), Siyasi İstikrarsızlık ve Ekonomik Performans: Türkiye Örneği, Ege Akademik Bakış Dergisi, Cilt:11, Say1:1, ss.73-80. Available: http://www.acarindex.com/dosyalar/makale/acarindex.pdf.

Asteriou, D. ve Price, S. (2001), Political Instability and Economic Growth: UK Time Series

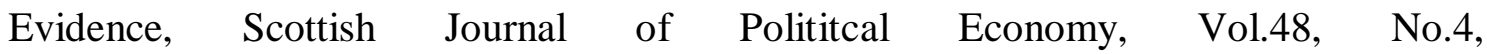
Available:http://econpapers.repec.org/article/blascotjp.

Berthelemy, J.C. ve Kauffmann, C. ve Renard, L. ve Wegner, L. (2002), Political Instability, Political Regimes And Economic Performance in African Countries, The OECD Development Center, Working Paper, Available:http://citeseerx.ist.psu.edu/viewdoc/downlodoi=10.1.1.458.7484.pdf.

Compos, N.F ve Karanasos, M.G. ve Tan, B. (2012), Two to tangle: Financial development, political instability and economic growth in Argentina, Journal of Banking \& Finance 36 (1), 290-304.

Diken, A. ve Parlakkaya, A. ve Kara, E. ve Kodalak, O. (2018), The Relation Between Political Stability and Economic Growth: TheTurkish Case Selçuk Üniversitesi Sosyal Bilimler Enstitüsü Dergisi, 40 (1), 176-185.

Doğan Çalışkan, Z. (2018), An Evaluatıon Upon The Relatıonshıp Of Polıtıcal Stabılıty And Economic Growth, in Economic and Managemen Issues in Retrospect and Prospect, 
Edited by: Eszter Wirth, Orhan Şimşek, Şükrü Apaydın, First Edition, November 2018 IJOPEC Publication No: 2018/37, ISBN: 978-1-912503-58-2 123-128.

Feng, Y. (1997), Democracy, Political Stability and Economic Growth. British Journal of Political Science, 27(3), 391-418. doi:10.1017/S0007123497000197

Fosu, A. K. (1992), Political Instability and Economic Growth, American Journal of Economics and Sociology, 61(1), Available: http://onlinelibrary.wiley.com/doi/10.1111/1536$7150.00162 / \mathrm{pdf}$.

Gurgul, H. ve Lach, L. (2013). Political İnstability And Economic Growth: Evidence From Two Decades of Transition in CEE, Communist And Post-Communist Studies No:46 (2013) pp.189-202, http://dx.doi.org/10.1016/j.postcomstud.2013.03.008

Gür, T.H. ve Akbulut, H. (2012). Gelişmekte Olan Ülkelerde Politik İstikrarın Ekonomik Büyüme Üzerindeki Etkisi, Sosyoekonomi Dergisi, Cilt:17, Say:17, pp. 281-301, Available :http://dergipark.ulakbim.gov.tr/sosyoekonomi/article/view/5000080634

Jong A Pin, R. (2008). Essays On Political Instability: Measurement, Causes And Consequences, Enschede:PrintPartners Ipskamp B.V. Enschede, The Netherlands, Available: http://www.rug.n1/research/portal/files/13152417/thesis.pdf.

Kalay, M. ve Çetin, D. (2016). Afrika Ülkelerinde Politik İstikrar ve Ekonomik Büyüme, İnsan ve Toplum Bilimleri Araştırmaları Dergisi, Cilt:5 Sayı:7 Sayfa:2277-2290, Available: http://dergipark.gov.tr/download/article-file/226746.

Karahan, H. ve Karagöl, E.T. (2014). Ekonomik Performansın Temel Taşı: Siyasi İstikrar, SETA Perspektif, Sayı:41, Available: http://file.setav.org/Files.pdf.

Koirala, B. ve Gyanwaly, R. P. ve Shresta, S. (2005). The Relationship Between Political Instability and Economic Growth in Nepal (1975-2003), Submitted to:South Asia Network of Economic Research Institutes (SANEI), New Delhi, India.

Kouba, L. ve Grochova L.(2011). Financial Crisis, Political İnstability And Economic Growth, The Czech Economy in the Process of Integration and Globalization, and the Development of Agricultural Sector and the Sector of Services under the New Conditions of the Integrated European Market", project no.01/2011, Available: https://ideas.repec.org/s/men/wpaper.html. 
Lipset, S. M. (1960). Political Man, Doubleday Company, NewYork, Available: https://ia800503.us.archive.org/25/items/politicalmansoci00inlips/politicalmansoci00inl ips.pdf.

Margolis, J.E. (2010), Understanding Political Stability and Instability, Civil Wars, 12 (3), 326345, DOI: $10.1080 / 13698249.2010 .509568$

Mbaku, J. (1988) Political İnstability And Economic Development in Sub-Saharan Africa: Some Recent Evidence, The Review of Black Political Economy, 89-103.

Morrison, D. G. ve Hugh M. S. (1972). Integration and instability: Patterns of African Political Development, American Political Science Review 66(3): 902-927.

Roe, M.J. Ve Siegel, J.I. (2011). Political Instability: Effects on Financial Development, Roots in the Severity of Economic İnequality, Journal of Comparative Economics 39 (2011) 279-309, doi:10.1016/j.jce.2011.02.001

Şanlısoy, S. ve Kök, R. (2010). Politik İstikrarsılık ve Ekonomik Büyüme İlişkisi: Kuznets Eğrisi Yaklaşımı, Finans, Politik ve Ekonomik Yorumlar Dergisi, Cilt:47, Sayı:541, ss.919, Erişim: http://kisi.deu.edu.tr//selim.sanlisoy.pdf.

Tabassam, A.H. ve Hashmi, S. H. ve Rehman, F. U. (2016). Nexus between Political Instability and Economic Growth in Pakistan, Procedia - Social and Behavioral Sciences No: 230, pp. 325-334, doi: 10.1016/j.sbspro.2016.09.041

Uddin, A.ve Ali, H. \& Masih, M. (2017). Political Stability And Growth: An Application Of Dynamic Gmm And Quantile Regression, Economic Modelling 64 (2017) 610-625, http://dx.doi.org/10.1016/j.econmod.2017.04.028 